\title{
Optimization of Blasting Parameters Using Regression Models in Ratcon and NSCE Granite Quarries, Ibadan, Oyo State, Nigeria
}

\author{
Jide Muili Akande, Abiodun Ismail Lawal \\ Department of Mining Engineering, The Federal University of Technology, Akure, Nigeria \\ Email: akandejn@yahoo.com, abiodunismail18@yahoo.com
}

Received September 28, 2012; revised November 13, 2012; accepted November 30, 2012

\begin{abstract}
This research examines optimization of blasting parameters for economic production of granite aggregates in Ratcon and NSCE quarries located at Ibadan, Oyo State. Samples were collected from the study areas for the determination of rock density and porosity. Schmidt hammer was used for in situ determination of rock hardness. Uniaxial compressive strength of in situ rock was estimated from the values obtained from Schmidt hammer rebound hardness test and density determined from laboratory test. Blasting data were collected from the study areas for optimization. Multiple regression analysis using computer aided solution SPSS (Statistical Package for the Social Sciences) was used to analyse data obtained from the laboratory test, field test and the study areas. The estimated mean uniaxial compressive strength value of NSCE is $240 \mathrm{MPa}$ and that of Ratcon is $200 \mathrm{MPa}$ and their average densities and average porosities are $2.63 \mathrm{~g} / \mathrm{cm}^{3}$, $2.55 \mathrm{~g} / \mathrm{cm}^{3}, 1.88 \%$ and $2.25 \%$ respectively. Eleven parameters were input into the multiple regression analysis to generate the models. Two parameters out of eleven input parameters such as geometric volume of blast $\left(\mathrm{Y}_{1}\right)$ and number of boulders generated after blasting $\left(\mathrm{Y}_{2}\right)$ were dependent variables and the remaining nine such as $\mathrm{X}_{1}$ (Drill hole diameter), $\mathrm{X}_{2}$ (Drill hole depth), $\mathrm{X}_{3}$ (Spacing), $\mathrm{X}_{4}$ (Burden), $\mathrm{X}_{5}$ (Average charge per hole), $\mathrm{X}_{6}$ (Rock density), $\mathrm{X}_{7}$ (Porosity), $\mathrm{X}_{8}$ (Uniaxial compressive strength) and $\mathrm{X}_{9}$ (Specific charge) were input as independent variables. The results of the models show that out of the nine independent variables seven of them that is $X_{1}$ (Borehole diameter), $X_{2}$ (Borehole depth), $\mathrm{X}_{3}$ (Spacing), $\mathrm{X}_{4}$ (Burden), $\mathrm{X}_{5}$ (Average charge per hole), $\mathrm{X}_{8}$ (Uniaxial compressive strength) and $\mathrm{X}_{9}$ (Specific charge) have significant contribution to the models while $X_{6}$ (Rock Density) and $X_{7}$ (Porosity) have insignificant contribution they are therefore automatically deleted by the SPSS. The result of the models developed for the optimization reveals that blasting number 5 gives the required product at lowest possible cost. From the result, the cost of secondary blasting has been reduced and volume of the blasted rock has been increased with low cost of explosives, the parameters that give this result have been chosen as optimum parameters.
\end{abstract}

Keywords: Blasting Parameters; Optimization; Multiple Regression Analysis; Schmidt Hammer; Uniaxial Compressive Strength; Density; Porosity; Models

\section{Introduction}

Efficiency of blasting operation in underground and surface mines determine to a large extent utilization of equipment, productivity and economics. Proper fragmentation of blasted rocks and coal improves the efficiency of downstream operations, viz. loading, transport and crushing to desired sizes. An optimal blast not only results in proper fragmentation but also reduces undesirable effects like ground vibration, fly rock and formation of toe in quarry benches [1]. The drilling and blasting is the first unit operations in the mining process and has a major impact on the performance and cost of subsequent unit operations. An increase in the degree of fragmentation will give the loading equipment a higher rate of productivity. This will result in lower costs per ton or cubic yard moved. The effect of wear and tear will also decrease, giving lower operating cost per hour. Under similar conditions of haul, lift, size and type of truck, and haul road condition, truck production per hour will increase with greater degree of fragmentation due to faster shovel or loader loading rates and a decrease in bridging at the crusher. There will be a consequent decrease in cycle time.

Fragmentation optimization involves breaking of rocks to ensure quality control, safe, consistent and efficient blasting. Big boulder or the opposite, excess fines can result from poorly selected drilling and blasting pattern. A well-selected pattern would produce fragmentation that can be accommodated by available loading and 
hauling equipment and crushing plant with little or no need for secondary blasting. It is well accepted that performance of basic mining operations such as excavation and crushing relies on a fragmentation which has been pre-conditioned by the blast, by pre-condition it means well fragment, sufficiently loose with adequate muck pole profile [2].

Effectiveness of hard rock blasting are measured with two basic indices that are oversize generation and blasthole productivity, cost per ton of rock blasted is also another index that measures the effectiveness of blasting and are dependent on rockmass and blast design parameters such as hole diameter, burden, spacing among others. [3] pointed out that the determinant parameters differ from one mine to the other and some of the blast design parameters could be regulated to deliver the desired blasting effectiveness. The individual influence of the determinant parameters on blasting effectiveness has been studied by several authors, but their cumulative influence on the same is yet to be formulated. However, the huge statistical data generated from the well organizes and documented large scale hard rock surface mines operating variable conditions worldwide constitutes the only readily available resource which could be used for the analysis and regression models of indices that determine effectiveness of blasting of the rock blasted fit on uncontrollable and controllable blasting parameters.

This research work is carried out to optimize blasting parameters by establishing relationship between the parameters and determining which of the parameters give the optimum blasting result using the regression model generated using indices such as oversize generation and geometric volume of blast fit on blast design parameters.

\section{Description of the Study Areas}

The study areas are located at Ibadan, Oyo state. Two quarries namely NSCE quarry and Ratcon quarry were used for this research. These quarries produce granite aggregates such as $1 / 2^{11}, 3 / 4^{11}$, lumps and quarry dust. The two quarries are in full operation. Figure 1 shows the Geological Map of Ratcon and NSRC Granite Quarries in Ibadan, Oyo State extracted from the Geological Map of Nigeria.

\section{Materials and Methods}

\subsection{Sample Collection and Preparation}

Samples were collected from two different quarries and GPS (global positioning system) was used to take the locations of where the samples were taken. The Samples were randomly taken from quarries' faces at four different points to ensure true representation of the rock. Samples from NSRC quarry were taken at longitude $07^{\circ} 15^{\prime} 22.9^{\prime \prime} \mathrm{N}$ and latitude $003^{\circ} 50^{\prime} 11.9^{\prime \prime}$ at $179 \mathrm{~m}$ above

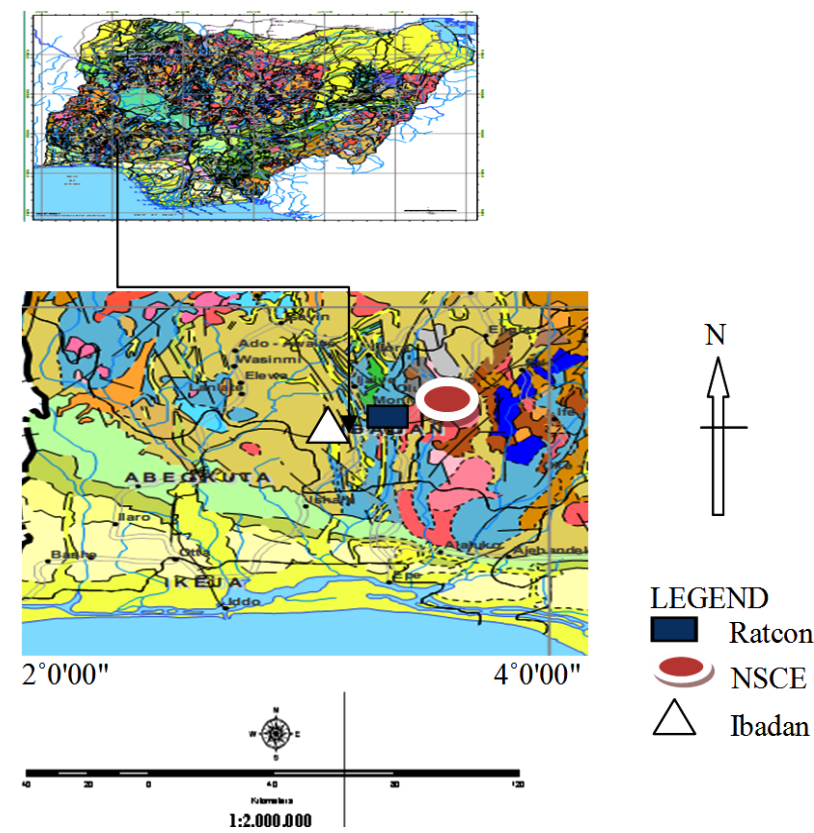

Figure 1. Geological map of Ratcon and NSCE granite quarries in Ibadan, Oyo state extracted from the geological map of Nigeria.

sea level, while those from Ratcon quarry were taken at longitude $07^{\circ} 16^{\prime} 59.9^{\prime \prime}$ and latitude $003^{\circ} 50^{\prime} 48.5^{\prime \prime}$ at $171 \mathrm{~m}$ above sea level. These samples were used for the determination of physical properties of the rock. Preparation of the samples follows the relevant ISRM and ASTM standard as much as practicable. Schmidt hammer was used to determine the strength of the rock.

\subsection{Determination of Rock Bulk Density}

The objective of the test is to measure the dry density of the rock samples of irregular form from Ratcon and NSCE granite quarries. The saturation and Buoyancy technique for irregular rock samples was adopted and the procedures follow the standard suggested by [4] and conform to [5].

The bulk and pore volumes were calculated as follows:

Bulk volume

$$
V=\frac{M_{\text {sat }}-M_{\text {sub }}}{p_{w}}
$$

Pore volume

$$
V_{V}=\frac{M_{\text {sat }}-M_{s}}{p_{w}}
$$

Bulk density of rock

$$
p_{b}=\frac{\text { mass }}{V}
$$

where $M_{\text {sat }}$ is the saturated-surface-dry mass, $M_{\text {sub }}$ is the saturated-submerged mass, $M_{s}$ is the grain weight and $p_{w}$ 
is the density of water.

\subsection{Porosity}

The objective of the test is to measure the porosity of rock specimens of irregular form. The porosity is the volume of pores in the rock expressed as a percentage of the total volume of the rock.

The saturation and Buoyancy technique for irregular rock samples was adopted and the procedures follow the standard suggested by [4] and conform to [5].

Porosity

$$
n=\frac{100 V_{V}}{V} \%
$$

where $V_{v}$ is the pore volume in $\mathrm{cm}^{3}$ and $V$ is the bulk volume in $\mathrm{cm}^{3}$.

\subsection{Hardness}

Hardness test involve the use of Schmidt Impact Hammer of type L for the hardness determination of in situ rock. The rebound value of the Schmidt Hammer is used as an index value for the intact strength of rock material, but it is also used to give an indication of the compressive strength of rock material [5].

The result of the hardness test is used to evaluate the unconfined compressive strength (UCS). The standard method for the Schmidt Hammer test as described by [4] and [5] was followed.

The measured test values were ordered in descending order. The lower $50 \%$ of the values were discarded and the average obtained of the upper $50 \%$ value to obtain the Schmidt Rebound Hardness [4].

\subsection{Uniaxial Compressive Strength}

The uniaxial compressive strength of the rock was estimated from the values of the type L Schmidt Hammer Hardness and the density of the rock.

The UCS values were estimated by using the chart named after Deere and Miller (1966) (Figure 2). The chart relates the Schmidt rebound hardness number, rock density and uniaxial compressive strength.

\subsection{Model Development}

Regression models for the optimization of blasting parameters of granite quarry were generated from the data collected, in-situ test and laboratory test conducted on two quarries that is Ratcon and NSRC quarries located at Ibadan, Oyo State. The standard statistical correlationregression analysis software (SPSS) was used to generate the regressions models of geometric volume of blasting $V_{B}$ and number of boulders generated $N_{B}$, fit on uncontrollable blasting parameters of (hardness, uniaxial com- pressive strength, and density) and controllable blasting parameters (burden, spacing, bench height, borehole diameter, average charge per hole etc). In these models both geometric volume $\left(V_{B}\right)$ of blast and number of boulders $\left(N_{B}\right)$ generated are dependent variables while blast design parameters such as burden $(B)$, Spacing $(S)$, Borehole Diameter $(D)$, Borehole depth $(H)$, Average Charge per Hole $(A G H)$, Porosity $(P)$, Compressive strength $\left(\sigma_{c}\right)$, Specific charge $(S C)$ and Density $(\rho)$ are independent parameters.

$$
\begin{aligned}
V_{B} & =f\left\{\sigma_{c}, \rho, B, S, D, H, A G H, P, S C\right\} \\
N_{B} & =f\left\{\sigma_{c}, \rho, B, S, D, H, A G H, P, S C\right\}
\end{aligned}
$$

\section{Results and Discussion}

Tables 1-4 show the results of laboratory tests conducted on rock samples from Ratcon and NSCE quarries for the determination of density and porosity. Table 5 shows the results of field test conducted on in situ rocks in the study areas with Schmidt hammer, density from laboratory test and estimated uniaxial compressive strength. Table 6 shows the blasting variables obtained from the study areas.

Table 1. Density of rock samples from Ratcon.

\begin{tabular}{cccccc}
\hline $\mathbf{S} / \mathbf{N}$ & $\mathbf{M}_{\text {sat }}(\mathbf{g})$ & Mass $(\mathbf{g})$ & $\mathbf{M}_{\text {sub }}(\mathbf{g})$ & $\mathbf{V}\left(\mathbf{c m}^{3}\right)$ & $\boldsymbol{\rho}\left(\mathbf{g} / \mathbf{c m}^{3}\right)$ \\
\hline $\mathbf{1}$ & 90 & 60 & 70 & 20 & 3.0 \\
$\mathbf{2}$ & 95 & 55 & 70 & 25 & 2.2 \\
$\mathbf{3}$ & 110 & 60 & 80 & 30 & 2.0 \\
$\mathbf{4}$ & 130 & 90 & 100 & 30 & 3.0 \\
\hline
\end{tabular}

Table 2. Density of rock samples from NSCE.

\begin{tabular}{cccccc}
\hline $\mathbf{S} / \mathbf{N}$ & $\mathbf{M}_{\text {sat }}(\mathbf{g})$ & Mass (g) & $\mathbf{M}_{\text {sub }}(\mathrm{g})$ & $\mathbf{V}\left(\mathbf{c m}^{3}\right)$ & $\boldsymbol{\rho}\left(\mathbf{g} / \mathbf{c m}^{3}\right)$ \\
\hline $\mathbf{1}$ & 80 & 50 & 60 & 20 & 2.5 \\
$\mathbf{2}$ & 80 & 50 & 60 & 25 & 2.5 \\
$\mathbf{3}$ & 80 & 50 & 60 & 30 & 2.5 \\
$\mathbf{4}$ & 120 & 90 & 60 & 30 & 3.0 \\
\hline
\end{tabular}

Table 3. Porosity of rock samples from Ratcon.

\begin{tabular}{cccc}
\hline $\mathbf{S} / \mathbf{N}$ & $\mathbf{V}\left(\mathbf{c m}^{3}\right)$ & $\mathbf{V}\left(\mathbf{c m}^{3}\right)$ & Porosity (\%) \\
\hline $\mathbf{1}$ & 0.20 & 10 & 2.0 \\
$\mathbf{2}$ & 0.30 & 12 & 2.5 \\
$\mathbf{3}$ & 0.42 & 14 & 3.0 \\
$\mathbf{4}$ & 0.18 & 12 & 1.5 \\
\hline
\end{tabular}




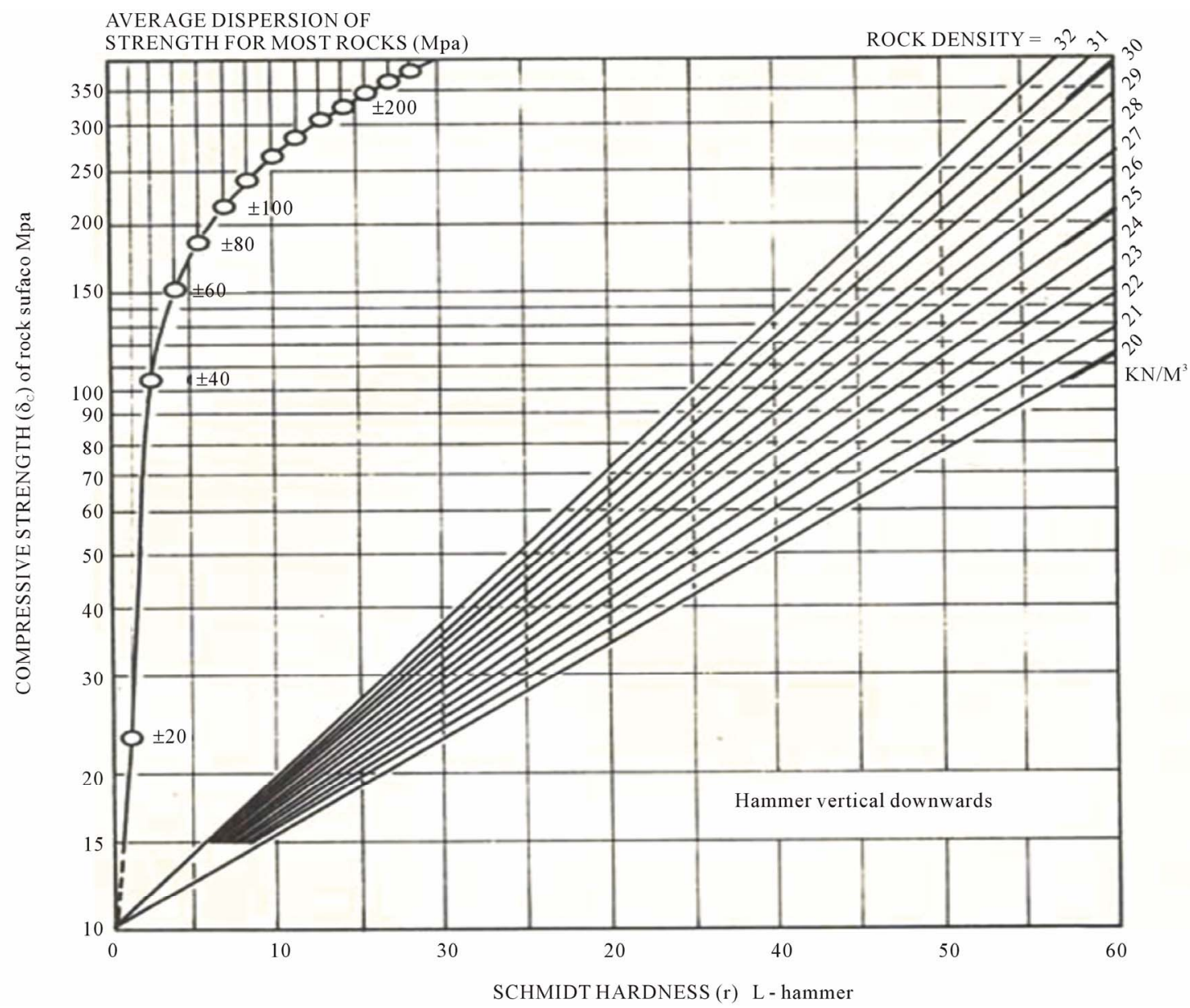

Figure 2. Correlation chart for schmidt (l) hammer, relating rock density, compressive strength and rebound number (after [6]).

Table 4. Porosity of rock samples from NSCE.

\begin{tabular}{cccc}
\hline $\mathbf{S} / \mathbf{N}$ & $\mathbf{V}\left(\mathbf{c m}^{3}\right)$ & $\mathbf{V}\left(\mathbf{c m}^{3}\right)$ & Porosity (\%) \\
\hline $\mathbf{1}$ & 0.24 & 12 & 2.0 \\
$\mathbf{2}$ & 0.20 & 10 & 2.0 \\
$\mathbf{3}$ & 0.20 & 10 & 2.0 \\
$\mathbf{4}$ & 0.18 & 12 & 1.5 \\
\hline
\end{tabular}

Table 5. Results of schmidt hammer tests for the determination of uniaxial compressive strength.

\begin{tabular}{cccc}
\hline $\begin{array}{c}\text { Granite } \\
\text { Location }\end{array}$ & $\begin{array}{c}\text { Average } \\
\text { Schmidt } \\
\text { Hammer } \\
\text { Result }\end{array}$ & $\begin{array}{c}\text { Average Density } \\
\text { from Laboratory } \\
\left.\text { Tests (g/cm } \mathbf{c m}^{\mathbf{2}}\right)\end{array}$ & $\begin{array}{c}\text { Equivalent } \\
\text { Uniaxial } \\
\text { Compressive } \\
\text { Strength (MPa) }\end{array}$ \\
\hline Ratcon & 59 & 2.55 & 200 \\
NSCE & 62 & 2.63 & 240 \\
\hline
\end{tabular}

\subsection{Model 1}

The value of $R^{2}$ is 0.984 and the adjusted $R^{2}$ is 0.979
(Table 8) showing that nine predictors entered in the regression analysis account for $98.4 \%$ of the variation in the geometric volume of blasted rock, while the F change is 193.239 (Table 8) and is much greater than 1, this shows that the model is significantly better at predicting volume of rock blasted rather than using means as a guess. The following parameters were found to be significant for volume of rock blasted; $\mathrm{X}_{1}$ (Borehole diameter), $\mathrm{X}_{2}$ (Borehole depth), $\mathrm{X}_{3}$ (Spacing), $\mathrm{X}_{4}$ (Burden), $\mathrm{X}_{5}$ (Average charge per hole), $\mathrm{X}_{8}$ (uniaxial compressive strength) and $\mathrm{X}_{9}$ (Specific charge). The parameters that are found insignificant are porosity and density of rock. Table 7 shows the computation for Model 1.

\subsection{Explanation of Parameters and Their Coefficients}

1) Blast-hole diameter $\left(X_{1}\right)(10.679)$ : This value that is 10.679 indicates that as the borehole diameter increases by one unit, the volume of rock blasted increases by 10.679units. This interpretation is true only if the effects of other parameters are held constant. The t-test (0.561) 
Table 6. Blasting variables obtained from NSCE and Ratcon.

\begin{tabular}{|c|c|c|c|c|c|c|c|c|c|c|}
\hline $\mathrm{X}_{1}$ & $\mathrm{X}_{2}$ & $X_{3}$ & $\mathrm{X}_{4}$ & $\mathrm{X}_{5}$ & $X_{6}$ & $\mathrm{X}_{7}$ & $\mathrm{X}_{8}$ & $\mathrm{X}_{9}$ & $\mathrm{Y}_{1}$ & $\mathrm{Y}_{2}$ \\
\hline 76.2 & 9 & 2.3 & 2.2 & 20.50 & 2.55 & 2.25 & 200 & 0.32 & 2914.56 & 20 \\
\hline 76.2 & 10 & 2.3 & 2.3 & 22.50 & 2.55 & 2.25 & 200 & 0.43 & 3385.60 & 25 \\
\hline 88.9 & 12 & 2.6 & 2.5 & 24.17 & 2.55 & 2.25 & 200 & 0.31 & 4680.00 & 25 \\
\hline 76.2 & 12 & 2.6 & 2.4 & 23.20 & 2.55 & 2.25 & 200 & 0.31 & 4792.32 & 30 \\
\hline 88.9 & 15 & 2.6 & 2.4 & 27.20 & 2.55 & 2.25 & 200 & 0.29 & 4792.32 & 30 \\
\hline 88.9 & 15 & 2.6 & 2.6 & 27.20 & 2.55 & 2.25 & 200 & 0.27 & 6084.00 & 30 \\
\hline 76.2 & 9 & 2.3 & 2.1 & 20.50 & 2.55 & 2.25 & 200 & 0.47 & 2608.20 & 20 \\
\hline 76.2 & 10 & 2.3 & 2.3 & 22.50 & 2.55 & 2.25 & 200 & 0.43 & 3174.00 & 20 \\
\hline 76.2 & 10 & 2.3 & 2.3 & 22.50 & 2.55 & 2.25 & 200 & 0.43 & 3385.60 & 25 \\
\hline 76.2 & 9 & 2.3 & 2.3 & 20.50 & 2.55 & 2.25 & 200 & 0.43 & 3047.04 & 20 \\
\hline 76.2 & 9 & 2.3 & 2.2 & 20.50 & 2.55 & 2.25 & 200 & 0.45 & 2732.40 & 25 \\
\hline 76.2 & 9 & 2.3 & 2.1 & 20.50 & 2.55 & 2.25 & 200 & 0.47 & 2782.08 & 20 \\
\hline 88.9 & 15 & 2.6 & 2.1 & 27.20 & 2.55 & 2.25 & 200 & 0.33 & 4914.00 & 20 \\
\hline 88.9 & 12 & 2.6 & 2.2 & 24.17 & 2.55 & 2.25 & 200 & 0.35 & 4118.40 & 25 \\
\hline 76.2 & 9 & 2.3 & 2.3 & 20.50 & 2.55 & 2.25 & 200 & 0.43 & 3047.04 & 20 \\
\hline 76.2 & 9 & 2.3 & 2.3 & 20.50 & 2.55 & 2.25 & 200 & 0.43 & 2856.60 & 25 \\
\hline 76.2 & 10 & 2.3 & 2.3 & 22.50 & 2.55 & 2.25 & 200 & 0.43 & 3385.60 & 25 \\
\hline 88.9 & 12 & 2.6 & 2.4 & 24.17 & 2.55 & 2.25 & 200 & 0.32 & 4492.80 & 20 \\
\hline 88.9 & 12 & 2.6 & 2.5 & 24.17 & 2.55 & 2.25 & 200 & 0.31 & 4992.00 & 20 \\
\hline 88.9 & 15 & 2.6 & 2.6 & 27.20 & 2.55 & 2.25 & 200 & 0.27 & 6084.00 & 20 \\
\hline 76.2 & 3 & 1.5 & 1.1 & 5.94 & 2.63 & 1.88 & 240 & 1.20 & 549.45 & 10 \\
\hline 76.2 & 3 & 2.0 & 1.8 & 6.00 & 2.63 & 1.88 & 240 & 0.56 & 1198.80 & 10 \\
\hline 76.2 & 3 & 1.5 & 1.5 & 5.94 & 2.63 & 1.88 & 240 & 0.88 & 540.00 & 10 \\
\hline 76.2 & 3 & 1.5 & 1.5 & 5.94 & 2.63 & 1.88 & 240 & 0.88 & 749.25 & 6 \\
\hline 76.2 & 3 & 2.0 & 2.0 & 6.00 & 2.63 & 1.88 & 240 & 0.50 & 960.00 & 6 \\
\hline 76.2 & 3 & 2.0 & 1.8 & 6.00 & 2.63 & 1.88 & 240 & 0.56 & 1198.80 & 10 \\
\hline 76.2 & 3 & 1.5 & 1.4 & 5.94 & 2.63 & 1.88 & 240 & 0.94 & 699.30 & 10 \\
\hline 76.2 & 3 & 1.5 & 1.5 & 5.94 & 2.63 & 1.88 & 240 & 0.88 & 749.25 & 10 \\
\hline 76.2 & 3 & 2.0 & 2.0 & 5.94 & 2.63 & 1.88 & 240 & 0.50 & 960.00 & 6 \\
\hline 76.2 & 3 & 1.5 & 1.5 & 6.00 & 2.63 & 1.88 & 240 & 0.89 & 749.25 & 6 \\
\hline
\end{tabular}

associated with this value shows that it is significant. Borehole diameter is making significant contribution to the model.

2) Blast-hole depth $\left(X_{2}\right)$ (535.401): This value indicates that as the borehole depth increases by one unit, the volume of rock blasted increases by 535.401units. This interpretation is true only if the effects of other parameters are held constant. The t-test (3.186) associated with this value shows that it is significant. Borehole diameter is making significant contribution to the model.

3) Spacing $\left(X_{3}\right)(1029.503)$ : This value indicates that as the spacing increases by one unit, the volume of rock blasted increases by 1029.503 units. This interpretation is true only if the effects of other parameters are held constant. The t-test (1.556) associated with this value shows that it is significant. Spacing between the holes is making 
Table 7. Computation for model 1. Dependent variable $\mathbf{Y}_{1}$.

\begin{tabular}{cccccc}
\hline Model & B & Std. Error & Beta & t & Sig. \\
\hline Constant & -6433.610 & 8618.775 & - & -0.746 & 0.463 \\
$\mathrm{X}_{1}$ & 10.679 & 19.051 & 0.035 & 0.561 & 0.581 \\
$\mathrm{X}_{2}$ & 535.401 & 168.033 & 1.337 & 3.186 & 0.004 \\
$\mathrm{X}_{3}$ & 1029.503 & 661.625 & 0.238 & 1.556 & 0.134 \\
$\mathrm{X}_{4}$ & 2219.330 & 516.477 & 0.506 & 4.297 & 0.000 \\
$\mathrm{X}_{5}$ & -166.731 & 153.668 & -0.815 & -1.085 & 0.290 \\
$\mathrm{X}_{8}$ & -6.407 & 34.425 & -0.071 & -0.186 & 0.854 \\
$\mathrm{X}_{9}$ & 2641.507 & 1012.697 & 0.367 & 2.608 & 0.016 \\
\hline
\end{tabular}

Table 8. Model 1 summary.

\begin{tabular}{ccccccc}
\hline Model & R & R Square & Adjusted R Square & Std. Error of the Estimate & R Square Change & F Change \\
\hline $\mathbf{1}$ & $0.992^{\mathrm{a}}$ & 0.984 & 0.979 & 251.7739045 & 0.984 & 193.239 \\
\hline
\end{tabular}

${ }^{\mathrm{a}}$ Power of $\mathrm{R}$.

significant contribution to the model.

4) Burden $\left(X_{4}\right)$ (2219.330): This value indicates that as the burden increases by one unit, the volume of rock blasted increases by 2219.330 units. This interpretation is true only if the effects of other parameters are held constant. The t-test (4.297) associated with this value shows that it is significant.

5) Average charge per hole $\left(X_{5}\right)(-66.731)$ : This value indicates that as the average charge per hole increases by one unit, the volume of rock blasted decreases by 66.731 units. This interpretation is true only if the effects of other parameters are held constant. The t-test $(-1.085)$ associated with this value shows that average charge per hole as a significant effect on volume of rock blasted.

6) Uniaxial compressive strength (-6.407): This value indicates that as the rock density increases by one unit, the volume of rock blasted decreases by 6.407 units. This interpretation is true only if the effects of other parameters are held constant. The t-test $(-0.186)$ associated with this value shows that it is significant. Rock density makes significant contribution to the model.

7) Specific charge $\left(X_{9}\right)$ (2461.507): This value indicates that as the specific charge increases by one unit, the volume of rock blasted increases by 2641.507 units. This interpretation is true if the effects of other parameters are held constant. The t-test $(0.367)$ associated with this value shows that it is significant.

\subsection{Model 2}

The value of $R^{2}$ is 0.876 (Table 10) showing that the nine predictors entered in the regression analysis account for $87.6 \%$ of the variation in number of boulders generated, while the F change is 22.192 (Table 10) and this is greater than one $(\mathrm{F}>1)$, this shows that the model is significantly better at predicting the number of oversize generated after blasting rather than using means as a guess. The following parameters were found to be significant for number of oversize generated after blasting; $\mathrm{X}_{1}$ (Borehole diameter), $\mathrm{X}_{2}$ (Borehole depth), $\mathrm{X}_{3}$ (Spacing), $X_{4}$ (Burden), $X_{5}$ (Average charge per hole), $X_{8}$ (compressive strength) and $\mathrm{X}_{9}$ (Specific charge). The parameters that are found insignificant are porosity and density of the rock. Table 9 shows the computation for Model 2.

\subsection{Explanation of Parameters and Their Coefficient}

1) Drillhole diameter $\left(X_{1}\right)(-0.471)$ : This value indicates that as the borehole diameter increases by one unit, number of boulders generated decreases by 0.471 units. This interpretation is possible if the effects of other parameters in the model are kept constant. The t-test $(-1.970)$ associated with this value shows that it is significant. Borehole diameter is making significant contribution to the model.

2) Drilhole depth $\left(X_{2}\right)$ (1.567): This value indicates that as the borehole diameter increases by one unit, number of boulders generated after blasting increases by 1.567 units. This interpretation is possible if the effects of other parameters are kept constant. The t-test (0.743) associated with this value shows that it is significant. Borehole depth is significantly contributing into the model.

3) Spacing $\left(X_{3}\right)$ (9.615): This value indicates that as the borehole diameter increases by one unit, number of boulders generated after blasting increases by 9.615 
Table 9. Computation for model 2.

\begin{tabular}{cccccc}
\hline Model & B & Std. Error & Beta & $\mathrm{t}$ & Sig. \\
\hline Constant & 25.119 & 108.216 & - & 0.232 & 0.819 \\
$\mathrm{X}_{1}$ & -0.471 & 0.239 & -0.344 & -1.970 & 0.062 \\
$\mathrm{X}_{2}$ & 1.567 & 2.110 & 0.867 & 0.743 & 0.466 \\
$\mathrm{X}_{3}$ & 9.615 & 8.307 & 0.492 & 1.157 & 0.260 \\
$\mathrm{X}_{4}$ & 5.324 & 6.485 & 0.269 & 0.821 & 0.420 \\
$\mathrm{X}_{5}$ & -0.173 & 1.929 & -0.187 & -0.090 & 0.929 \\
$\mathrm{X}_{8}$ & -0.098 & 0.432 & -0.240 & -0.226 & 0.823 \\
$\mathrm{X}_{9}$ & 18.061 & 12.715 & 0.557 & 1.420 & 0.170 \\
\hline
\end{tabular}

Table 10. Model 2 summary.

\begin{tabular}{ccccccc}
\hline Model & $\mathrm{R}$ & $\begin{array}{c}\mathrm{R} \\
\text { Square }\end{array}$ & $\begin{array}{c}\text { Adjusted R } \\
\text { Square }\end{array}$ & $\begin{array}{c}\text { Std. Error of } \\
\text { the Estimate }\end{array}$ & $\begin{array}{c}\text { R Square } \\
\text { Change }\end{array}$ & $\begin{array}{c}\mathrm{F} \\
\text { Change }\end{array}$ \\
\hline 1 & $0.936^{\mathrm{a}}$ & 0.876 & 0.836 & 3.161 & 0.876 & 22.192 \\
\hline
\end{tabular}

${ }^{\mathrm{a}}$ Power of R.

units. This interpretation is possible if the effects of other variables are kept constant. The t-test (1.157) associated with this value shows that it is significant. Spacing is making significant contribution to the model.

4) Burden $\left(X_{4}\right)$ (5.324): This value indicates that as the borehole diameter increases by one unit, number of boulders generated after blasting increases by 5.324 units. This interpretation is possible if the effects of other parameters are kept constant. The t-test $(0.821)$ associated with this value shows that it is significant. Burden makes significant contribution to the model.

5) Average charge per hole $\left(X_{5}\right)(-0.173)$ : This value indicates that as the average charge per hole increases by 1 unit, number of boulders generated decreases by 0.173 unit. This interpretation is possible if the effects of other parameters are kept constant. The t-test $(-0.90)$ associated with this value shows that it is significant. Average charge per hole is making significant contribution to the model.

6) Uniaxial compressive strength $\left(X_{8}\right)(-0.098)$ : This value indicates that as the rock density increases by 1 unit, number of boulders generated decreases by 0.098 units. This interpretation is true if the effects of other parameters are kept constant. The t-test $(-0.240)$ associated with this value shows that it is significant. Rock density is making significant contribution to the model.

7) Specific charge $\left(X_{9}\right)(18.061)$ : This value indicates that as the specific charge increases by one unit, the volume of rock blasted increases by 18.061 units. This interpretation is true if the effects of other parameters are held constant. The t-test (1.420) associated with this value shows that it is significant. Specific charge is mak- ing significant contribution to the model.

The estimation regression models for the volume of rock blasted and boulders generated after blasting for the determination of optimum parameters are written in Equations (7) to (10):

$$
\begin{aligned}
\mathrm{Y}_{1}= & -6433.610+10.679 \mathrm{X}_{1}+535.40 \mathrm{X}_{2} \\
& +1029.503 \mathrm{X}_{3}+2219.330 \mathrm{X}_{4}-166.731 \mathrm{X}_{5} \\
& -6.407 \mathrm{X}_{8}+2461.507 \mathrm{X}_{9} \\
\mathrm{Y}_{2}= & 25.119-0.471 \mathrm{X}_{1}+1.567 \mathrm{X}_{2}+9.615 \mathrm{X}_{3} \\
& +5.324 \mathrm{X}_{4}-0.173 \mathrm{X}_{5}-0.098 \mathrm{X}_{8}+18.061 \mathrm{X}_{9}
\end{aligned}
$$

By replacing $\mathrm{X}$ and $\mathrm{Y}$ with symbols of parameters, Equations (7) and (8) become;

$$
\begin{aligned}
V_{B}= & -6433.610+10.679 D+535.401 \mathrm{H} \\
+ & 1029.503 S+2219.330 B-166.731 \mathrm{ACH} \\
- & 6.407 U C S+2461.507 Q_{C} \\
N_{B}= & 25.119-0.471 D+1.567 \mathrm{H} \\
& +9.615 S+5.324 B-0.173 \mathrm{ACH} \\
& -0.098 U C S+18.061 Q_{C}
\end{aligned}
$$

\subsection{Model Discussion}

The impact of the blasting parameters on the granite aggregate production blasting could be explained in accordance to the regression models estimated for geometric volume of rock blasted and number of boulders generated as follows:

Blast-hole Diameter: As the borehole diameter increases, the geometric volume of rock blasted increases Equation (9) and the number of boulders generated decreases Equation (10), resulting to decrease in the cost of secondary blasting. This agreed with [7] which states that when the specific charge of explosive (charge per unit volume of blasted rock) is constant, larger diameter boreholes generally result in lower total blasting cost. Smaller boreholes will cause more loss of explosive energy than larger ones. [8] also stated that smaller diameter borehole will only favour powder factor.

Blast-hole Depth: As blast-hole depth increases, the geometric volume of rock blasted increases Equation (9). This assumption is true because as the drill-hole depth increases more explosive will be used and more volume of rock will be obtained, but this increment has limitation. It is limited by the rich of the loading equipment.

Spacing: As the hole spacing increases both the volume rock blasted and number of boulders increases Equations (9) and (10). This is because there are wider areas to be covered by the explosion gases this leads to increase in the number of boulders and consequently, increase in the cost of secondary blasting. However, the value of spacing must not be too small; this leads to excessive crushing between the holes, toe problems and 
lower volume of rock blasted.

Burden: As the hole burden increases, the volume of rock blasted increases and also number of boulders generated increases, but it has very little contribution to the increase in number of boulders as compared to that of volume of rock blasted (Equations (9) and (10)).

Average charge per hole: As the average charge per hole increases the volume of rock blasted and number of boulders generated decreases Equations (9) and (10). This is true because if the blast hole is over charged there will be more dust in the product of blasting than the required aggregates and eventually, there will be less number of boulders.

Uniaxial compressive strength: As the uniaxial compressive strength of rock increases the volume of rock blasted and number of boulders generated decreases Equations (9) and (10). As the rock strength increases volume of rock blasted decreases, resulting to increase in the cost of blasting because more explosive energy will be required to break the rock.

Specific charge: As specific charge increases, volume of rock blasted and number of boulders generated increase Equations (9) and (10). But care should be taking so as to avoid using more explosive than required.

Density of rock: as the density of rock increases the geometric volume of blast and number of boulders generated decreases. It has been identified by several researchers such as [8-10] among others that rock density hampers the transfer of explosive energy and thus blastability, cost of blasting and product of blasting, though it is found insignificant in the developed model.

\subsection{Discussions}

The field estimation of uniaxial compressive strength was determined using the Schmidt hammer method. The uniaxial compressive strength of NSRC granite is higher than that of Ratcon granite.

The average Schmidt hammer values of Ratcon and NSRC granite quarries as obtained from the field are shown in Tables $\mathbf{4}$ and $\mathbf{5}$ with their corresponding measured average density. From this result it can be observed that the Schmidt hammer value of Ratcon is lower than that of NSRC.

Density and porosity were also determined in FUTA Rock Mechanics laboratory (Tables 1-4). Rock samples from NSRC are denser than those gotten from Ratcon and the porosity of the formal is lower than that of the latter.

Both the mechanical properties and physical properties determined were used in the formulation of the optimization model.

The developed models reveal that out of nine blasting parameters (both controllable and uncontrollable) such as borehole diameter $\left(\mathrm{X}_{1}\right)$, borehole depth $\left(\mathrm{X}_{2}\right)$, hole spacing $\left(\mathrm{X}_{3}\right)$, burden $\left(\mathrm{X}_{4}\right)$, average charge per hole $\left(\mathrm{X}_{5}\right)$, density $\left(\mathrm{X}_{6}\right)$, porosity $\left(\mathrm{X}_{7}\right)$, uniaxial compressive strength $\left(\mathrm{X}_{8}\right)$, specific charge $\left(\mathrm{X}_{9}\right)$ that participated as independent variables in the models, only seven of them make significant contribution to the models, while the porosity and density of rock make insignificant contribution to the models, they were therefore removed from the model (Tables 11 and 12).

The models developed in Equations 9 and 10 were used to determine which of the input parameters give optimum result with little boulders. Table 6 shows the list of the parameters before using the model while Table $\mathbf{1 3}$ below shows the list of the parameters after using the model for optimization. From Table 13 blasting number 5 (Borehole diameter $=88.9 \mathrm{~mm}$, Borehole depth $=15 \mathrm{~m}$, Spacing $=2.6 \mathrm{~m}$, Burden $=2.4 \mathrm{~m}$, Density $=2.55 \mathrm{~g} / \mathrm{cm}^{3}, \mathrm{Av}$ erage Specific charge $=0.29 \mathrm{~kg} / \mathrm{m}^{3}$ ) gives the optimum parameters this result agreed with [2] who used Langarford formula for optimizing drilling and blasting pattern and discovered that the blasting pattern with specific charge of 0.29 gives the optimum result.

\section{Conclusions}

From the results of the research presented here, following conclusion were drawn:

The mechanical properties of the rock tested fall within the range of very high strength, although compressive strength of NSCE (240 MPa) is higher than that of Ratcon (200 MPa).

The average densities and average porosities of NSCE granite and Ratcon granite are $2.63 \mathrm{~g} / \mathrm{cm}^{3}, 2.55 \mathrm{~g} / \mathrm{cm}^{3}$, $1.88 \%$ and $2.25 \%$ respectively.

The value of $R^{2}$ values of the two models show that the nine predictors entered in the regression analysis account for $87.6 \%$ of the variation in number of boulders generated and $98.4 \%$ of the variation in the geometric

Table 11. Excluded variables. Excluded variables ${ }^{\text {b }}$

\begin{tabular}{cccccccc}
\hline & & & & & & \multicolumn{2}{c}{ Collinearity Statistics } \\
\cline { 3 - 7 } Model & Beta in & $\mathrm{t}$ & Sig. & Partial Correlation & Tolerance & VIF & Minimum Tolerance \\
\hline $\mathrm{X}_{6}$ & $0^{\mathrm{a}}$ & - & - & - & 0.000 & - & 0.000 \\
$\mathrm{X}_{7}$ & $0^{\mathrm{a}}$ & - & - & - & 0.000 & - & 0.000 \\
\hline
\end{tabular}

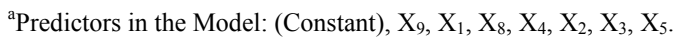


Table 12. Excluded variables from model. Excluded variables ${ }^{\mathrm{b}}$.

\begin{tabular}{|c|c|c|c|c|c|c|c|}
\hline \multirow{2}{*}{ Model } & \multirow{2}{*}{ Beta In } & \multirow{2}{*}{$\mathrm{t}$} & \multirow{2}{*}{ Sig. } & \multirow{2}{*}{ Partial Correlation } & \multicolumn{3}{|c|}{ Collinearity Statistics } \\
\hline & & & & & Tolerance & VIF & Minimum Tolerance \\
\hline $\mathrm{X}_{6}$ & $0^{\mathrm{a}}$ & - & - & - & 0.000 & - & 0.000 \\
\hline $\mathrm{X}_{7}$ & $0^{\mathrm{a}}$ & - & - & - & 0.000 & - & 0.000 \\
\hline
\end{tabular}

${ }^{\mathrm{a}}$ Predictors in the Model: (Constant), $\mathrm{X}_{9}, \mathrm{X}_{1}, \mathrm{X}_{8}, \mathrm{X}_{4}, \mathrm{X}_{2}, \mathrm{X}_{3}, \mathrm{X}_{5}$.

Table 13. After application of model (optimum table).

\begin{tabular}{|c|c|c|c|c|c|c|c|c|c|c|}
\hline $\mathrm{X}_{1}$ & $\mathrm{X}_{2}$ & $\mathrm{X}_{3}$ & $\mathrm{X}_{4}$ & $\mathrm{X}_{5}$ & $\mathrm{X}_{6}$ & $\mathrm{X}_{7}$ & $\mathrm{X}_{8}$ & $\mathrm{X}_{9}$ & $\mathrm{Y}_{1}$ & $\mathrm{Y}_{2}$ \\
\hline 76.2 & 10 & 2.3 & 2.2 & 20.50 & 2.55 & 2.25 & 200 & 0.32 & 2595.105 & 19.84 \\
\hline 76.2 & 10 & 2.3 & 2.3 & 22.50 & 2.55 & 2.25 & 200 & 0.43 & 3309.543 & 23.58 \\
\hline 88.9 & 12 & 2.6 & 2.5 & 24.17 & 2.55 & 2.25 & 200 & 0.31 & 4673.264 & 22.23 \\
\hline 76.2 & 13 & 2.6 & 2.4 & 23.20 & 2.55 & 2.25 & 200 & 0.31 & 4477.437 & 27.84 \\
\hline 88.9 & 14 & 2.6 & 2.4 & 27.20 & 2.55 & 2.25 & 200 & 0.29 & 5943.375 & 25.51 \\
\hline 88.9 & 15 & 2.6 & 2.6 & 27.20 & 2.55 & 2.25 & 200 & 0.27 & 5890.545 & 26.21 \\
\hline 76.2 & 9 & 2.3 & 2.1 & 20.50 & 2.55 & 2.25 & 200 & 0.47 & 2769.398 & 22.02 \\
\hline 76.2 & 10 & 2.3 & 2.3 & 22.50 & 2.55 & 2.25 & 200 & 0.43 & 3309.543 & 23.58 \\
\hline 76.2 & 10 & 2.3 & 2.3 & 22.50 & 2.55 & 2.25 & 200 & 0.43 & 3309.543 & 23.58 \\
\hline 76.2 & 9 & 2.3 & 2.3 & 20.50 & 2.55 & 2.25 & 200 & 0.43 & 3107.604 & 22.36 \\
\hline 76.2 & 9 & 2.3 & 2.2 & 20.50 & 2.55 & 2.25 & 200 & 0.45 & 2938.501 & 22.19 \\
\hline 76.2 & 9 & 2.3 & 2.1 & 20.50 & 2.55 & 2.25 & 200 & 0.47 & 2769.398 & 22.02 \\
\hline 88.9 & 15 & 2.6 & 2.1 & 27.20 & 2.55 & 2.25 & 200 & 0.33 & 4939.37 & 24.63 \\
\hline 88.9 & 12 & 2.6 & 2.2 & 24.17 & 2.55 & 2.25 & 200 & 0.35 & 4113.125 & 21.35 \\
\hline 76.2 & 9 & 2.3 & 2.3 & 20.50 & 2.55 & 2.25 & 200 & 0.43 & 3107.604 & 22.36 \\
\hline 76.2 & 9 & 2.3 & 2.3 & 20.50 & 2.55 & 2.25 & 200 & 0.43 & 3107.604 & 22.36 \\
\hline 76.2 & 10 & 2.3 & 2.3 & 22.50 & 2.55 & 2.25 & 200 & 0.43 & 3309.543 & 23.58 \\
\hline 88.9 & 12 & 2.6 & 2.4 & 24.17 & 2.55 & 2.25 & 200 & 0.32 & 4477.746 & 21.87 \\
\hline 88.9 & 12 & 2.6 & 2.5 & 24.17 & 2.55 & 2.25 & 200 & 0.31 & 4673.264 & 22.23 \\
\hline 88.9 & 15 & 2.6 & 2.6 & 27.20 & 2.55 & 2.25 & 200 & 0.27 & 5890.545 & 26.21 \\
\hline 76.2 & 3 & 1.5 & 1.1 & 5.94 & 2.63 & 1.88 & 240 & 1.20 & 613.701 & 11.39 \\
\hline 76.2 & 3 & 2.0 & 1.8 & 6.00 & 2.63 & 1.88 & 240 & 0.56 & 981.415 & 8.36 \\
\hline 76.2 & 3 & 1.5 & 1.5 & 5.94 & 2.63 & 1.88 & 240 & 0.88 & 656.151 & 7.74 \\
\hline 76.2 & 3 & 1.5 & 1.5 & 5.94 & 2.63 & 1.88 & 240 & 0.88 & 656.151 & 7.74 \\
\hline 76.2 & 3 & 2.0 & 2.0 & 6.00 & 2.63 & 1.88 & 240 & 0.50 & 1266.791 & 8.34 \\
\hline 76.2 & 3 & 2.0 & 1.8 & 6.00 & 2.63 & 1.88 & 240 & 0.56 & 981.415 & 8.36 \\
\hline 76.2 & 3 & 1.5 & 1.4 & 5.94 & 2.63 & 1.88 & 240 & 0.94 & 592.708 & 8.29 \\
\hline 76.2 & 3 & 1.5 & 1.5 & 5.94 & 2.63 & 1.88 & 240 & 0.88 & 656.151 & 7.74 \\
\hline 76.2 & 3 & 2.0 & 2.0 & 5.94 & 2.63 & 1.88 & 240 & 0.50 & 1276.795 & 8.35 \\
\hline 76.2 & 3 & 1.5 & 1.5 & 6.00 & 2.63 & 1.88 & 240 & 0.89 & 672.562 & 7.91 \\
\hline
\end{tabular}


volume of blast, while their $\mathrm{F}$ changes are far greater geometric volume of blast.

Blasting parameters used in blasting number 5 (Borehole diameter $=88.9 \mathrm{~mm}$, Borehole depth $=15 \mathrm{~m}$, Spacing $=2.6 \mathrm{~m}$, Burden $=2.4 \mathrm{~m}$, Density $=2.55 \mathrm{~g} / \mathrm{cm}^{3}, \mathrm{Av}-$ erage Specific charge $=0.29 \mathrm{~kg} / \mathrm{m}^{3}$ ) gives the optimum blasting product out of 30 blasting operations used in the models development.

\section{REFERENCES}

[1] C. V. B. Cunningham, "Control over Blasting Parameters and Its Effect on Quarry Productivity," AECI Explosives and Chemical Limited, Rondebosch, 2011, p. 2.

[2] M. A. Saliu and J. M. Akande, "Drilling and Blasting Pattern Selection for Fragmentation Optimization in Raycon Quarry," Journal of Engineering and Applied Sciences, Vol. 2, No. 12, 2007, p. 1768.

[3] A. T. S. Massawe and R. B. Karim, "Regression Models of the Impact of Rockmass and Blasting Design Variables on the Effectiveness of Iron Ore Surface Blasting," Department of Chemical and Mining Engineering College of Engineering and Technology, University of Dar es Salam, Dar es Salam, 2011, pp. 56-56.

[4] ISRM, "Rock Characterization, Testing on Monitoring," In: E. T. Brown, Ed., ISRM Suggested Methods, Perga- mon Press, Oxford, 1981, p. 211.

[5] ASTM, "Annual Book of ASTM Standards-Construction: Soil and Rocks," ASTM Publication, West Conshohocken, 1994, p. 975.

[6] D. U. Deere and R. P. Miller, "Engineering Classification and Index Properties for Intact Rock," Technical Report No. AFNL-TR-65-116, Air Force Weapon Laboratory, New Mexico, 1966.

[7] C. S. Sun, D. W. Later and G. Chen, "Analysis of the Effect of Borehole Size on Explosive Energy Loss in Rock Blasting," Fragblast: International Journal for Blasting and Fragmentation, Vol. 5, No. 4, 2001, pp. 235246. doi:10.1076/frag.5.4.235.3618

[8] C. L. Jimeno, E. L. Jimeno and J. A. C. Francisco, "Drilling and Blasting of Rock," Taylor \& Francis, New York, 1995.

[9] B. Bahman, "The Effects of Geological Parameters on Rock Blasting Using the Hopkinson Split Bar," International Journal of Rock Mechanics and Mining Sciences, Vol. 34, No. 3-4, 1997, pp. e1-e9.

[10] B. N. Kutuzov, B. I. Komashenko, B. F. Noskov, C. B. Gabrahamov and A. A. Muzirkov, "Lab and Practical Exercises in the Explosive Breakage of Rocks," Nedra, Moscow, 1981. 